\title{
Survey of Contaminated Percutaneous Injuries in Anesthesia Practitioners
}

Reine Zbeidy, MD, Joshua Livingstone, MD, Vadim Shatz, MD, Yehuda Raveh, MD, Rofayda Gad, MD, Ramona Nicolau-Raducu, MD, Fouad G. Souki, MD

Department of Anesthesiology, University of Miami, Jackson Health System, Miami, Florida, USA

Reine Zbeidy, MD

Title: Assistant Professor

Affiliation: Department of Anesthesiology, University of Miami, Jackson Memorial Hospital

Email: rzbeidy@med.miami.edu

Conflicts: Reine Zbeidy reported no conflicts of interest

Attestation: Reine Zbeidy approved the final manuscript

Joshua Livingstone, MD

Title: Assistant Professor

Affiliation: Department of Anesthesiology, University of Miami, Jackson Memorial Hospital

Email: jlivingstone@ med.miami.edu

Conflicts: Joshua Livingstone reported no conflicts of interest

Attestation: Joshua Livingstone approved the final manuscript

Vadim Shatz, MD

Title: Assistant Professor

Affiliation: Department of Anesthesiology, University of Miami, Jackson Memorial Hospital

Email: vshatz@med.miami.edu

Conflicts: Vadim Shatz reported no conflicts of interest

Attestation: Vadim Shatz approved the final manuscript

Yehuda Raveh, MD

Title: Associate Professor

Affiliation: Department of Anesthesiology, University of Miami, Jackson Memorial Hospital

Email: yraveh@med.miami.edu

Conflicts: Yehuda Raveh reported no conflicts of interest

Attestation: Yehuda Raveh approved the final manuscript

\section{Rofayda Gad, MD}

Title: Fellow

Affiliation: Department of Anesthesiology, University of Miami, Jackson Memorial Hospital

Email: Rofayda.gad@jhsmiami.org

Conflicts: Rofayda Gad reported no conflicts of interest

Attestation: Rofayda Gad approved the final manuscript 
medRxiv preprint doi: https://doi.org/10.1101/2021.01.21.21249920; this version posted February 28, 2021. The copyright holder for this preprint

(which was not certified by peer review) is the author/funder, who has granted medRxiv a license to display the preprint in perpetuity.

All rights reserved. No reuse allowed without permission.

\section{Ramona Nicolau-Raducu, MD}

Title: Associate Professor

Affiliation: Department of Anesthesiology, University of Miami, Jackson Memorial Hospital

Email: rxn256@med.miami.edu

Conflicts: Ramona Nicolau-Raducu reported no conflicts of interest

Attestation: Ramona Nicolau-Raducu approved the final manuscript

\section{Fouad G. Souki, MD}

Title: Associate Professor

Affiliation: Department of Anesthesiology, University of Miami, Jackson Memorial Hospital

Email: Fsouki@med.miami.edu

Conflicts: Fouad G. Souki reported no conflicts of interest

Attestation: Fouad G. Souki approved the final manuscript

\section{Corresponding author:}

Fouad G. Souki, MD

University of Miami/Jackson Health System

1611 NW 12 $2^{\text {th }}$ Ave, DTC 318

Miami 33136, FL, USA

Phone: 3055857435

Fax: 3055857477

Email: Fsouki@med.miami.edu

Financial disclosures: None.

Conflicts of interest: None.

Word count Abstract: 365

Word count Introduction: 110

Word count Discussion: 1300

Word count Entire body of text: 2090

Abbreviated title: Percutaneous Injuries in Anesthesiologists

\section{Author contributions:}

Reine Zbeidy, MD designed, analyzed, and wrote the manuscript

Joshua Livingstone, MD helped write the manuscript.

Vadim Shatz, MD helped write the manuscript.

Yehuda Raveh, MD helped write the manuscript.

Rofayda gad, MD helped with data collection and entry.

Ramona Nicolau-Raducu helped write the manuscript.

Fouad G. Souki, MD designed, analyzed, and wrote the manuscript 


\begin{abstract}
Background

Anesthesia practitioners are at inherent risk for percutaneous injuries by blood-contaminated needles and sharp objects. These exposures may result in transmission of HIV and hepatitis viruses. Data about this occupational hazard from contaminated needles and sharp devices is limited and decades old. We conducted a web-based survey to assess the occurrence, reporting, characteristics, and outcome of contaminated percutaneous injuries (CPI) in anesthesia residents, fellows, and attendings.
\end{abstract}

\title{
Methods
}

After institutional research board approval, an email was sent to 217 anesthesia practitioners requesting their participation in an online survey about contaminated percutaneous injuries. Responses were collected from February through March 2020. Results are reported as absolute numbers and proportions with $95 \%$ confidence interval (CI).

\section{Results}

The overall survey response rate was 51\% (110/217). 59\% (65/110) (95\% CI, 50-68) of participants reported having one or more contaminated percutaneous injury during their years of anesthesia practice $(42 \%(21 / 50)$ of residents, 50\% (4/8) of fellows, $77 \%$ (40/52) of anesthesia attendings). Prevalence of injuries related to attendings' years of anesthesia practice was $69 \%$ (95\% CI, 44-94) for 5-10 years, 62.5\% (95\% CI, 29-96) for 10-15 years, and 79\% (95\% CI, 6395) for greater than 15 years of practice.

$35 \%(95 \%$ CI, 26-44) of participants reported having one or more CPI within the last 5 years (40\% of residents, $50 \%$ of fellows, $29 \%$ of attendings). Occurrence of CPI within the last 5 years based on attending anesthesiologist years of practice was $57 \%$ for less than 5 years, $37.5 \%$ for 
10-15 years, and $20 \%$ for $15-20$ years of practice. $75 \%(95 \%$ CI, 65-85) reported the incident at the time of injury. 59\% (95\% CI, 48-70) of injuries were due to hollow bore needles. 50\% (95\% CI, 39-61) of total injuries were high risk. $26 \%$ of injured anesthesia practitioners received postexposure prophylaxis and there were zero seroconversions.

Conclusion: Most anesthesiologists will sustain a contaminated percutaneous injury during their careers. Incidence of these injuries decreases with years of practice. Occurrence of these injuries is high among anesthesia residents, with the majority reporting their injuries. Half of the injuries are high risk with a quarter requiring postexposure prophylaxis. More education and interventions are needed to reduce percutaneous injuries and improve reporting.

Keywords: Percutaneous injury, Occupational hazard, Anesthesia, Needlestick, Survey 


\section{Introduction}

Anesthesia practitioners are at occupational hazard for percutaneous injuries by bloodcontaminated needles and sharp objects. These exposures may result in transmission of HIV and hepatitis viruses. The risk of infection varies with the pathogen and type of exposure (e.g., superficial or deep, solid bore or hollow-bore needle) [1]. Data about the risk to anesthesia residents, fellows, and attendings from contaminated needles and other sharp devices is limited and decades old [2-7]. These injuries are often under reported which further hinders accurate data collection [6,7]. We conducted a web-based survey to assess the occurrence, reporting, characteristics, and outcome of contaminated percutaneous injuries (CPI) in anesthesia residents, fellows, and attendings. 


\section{Methods}

We obtained institutional research board approval to conduct a web-based survey to assess the occurrence, reporting, characteristics, and outcome of contaminated percutaneous injuries (CPI) in anesthesia residents, fellows, and attendings at a multihospital based anesthesia practice in south Florida, USA. An email was sent to all registered anesthesia practitioners (217) requesting their participation in an online survey. Respondents were informed that participation in the survey implied consent. Anesthesia practitioners consisted of 85 residents, 17 fellows, and 115 attendings. The survey was confidential and anonymous. No personal identifiers were collected, and the survey responses could not be traced back to responders. Non-delivered email was not reported. Since we could not identify responders and non-responders, a second email request for participation in the survey was sent after 2 weeks. Responses were collected from February through March 2020. The web-based survey was developed using SurveyMonkey ${ }^{\mathrm{R}}$ (Portland, OR) following guidelines to survey research in anesthesiology [8]. The survey was pilot tested with 10 anesthesiologists and adjustments were made based on their remarks. The survey consisted of nine close-response questions, and two open-response questions (Appendix). The closed-response questions inquired about age, gender, job title, years of anesthesia practice, number of contaminated percutaneous injuries, contaminated percutaneous injury within the last 5 years, injury reporting, postexposure prophylaxis, and seroconversion. In the two openresponse questions, respondents were asked to "choose all that apply" and/or provide a free-text answer about the device that caused injury and the presumed infectious status of source. SurveyMonkey ${ }^{\mathrm{R}}$ prevented duplication of responses by allowing only one response per electronic device behind the internet protocol address. Survey results were reported as absolute values and proportions with 95\% confidence interval (CI). Statistical analysis was performed using the 
medRxiv preprint doi: https://doi.org/10.1101/2021.01.21.21249920; this version posted February 28, 2021. The copyright holder for this preprint

(which was not certified by peer review) is the author/funder, who has granted medRxiv a license to display the preprint in perpetuity.

All rights reserved. No reuse allowed without permission.

normal approximation method, Wald's method, to calculate the 95\% CI for proportions $[9,10]$.

This manuscript adheres to the applicable EQUATOR guidelines (STROBE). 


\section{Results}

We received 110 responses out of 217 email invitations, a 51\% response rate. Survey completion rate was $99 \%$. $60 \%$ of respondents were males. Survey response rate was $59 \%(50 / 85)$ for residents, $47 \%$ (8/17) for fellows, and 45\% (52/115) for attendings. In all, 59\% (65/110) (95\% CI, 50-68) reported being injured percutaneously by a contaminated sharp object or needle (42\% (21/50) of residents, $50 \%$ (4/8) of fellows, 77\% (40/52) of anesthesia attendings) (Table 1). 54\% reported being injured once, $34 \%$ injured twice, $12 \%$ injured three or more times. Survey participants reported 113 CPIs. Numbers of CPIs per anesthesia practitioner who answered survey was 0.58 for residents, 0.75 for fellows, and 1.5 for attendings.

Prevalence of injuries related to attendings' years of anesthesia practice was 69\% (95\% CI, 4494) for 5-10 years, $62.5 \%$ (95\% CI, 29-96) for 10-15yrs, and 79\% (95\% CI, 63-95) for >15 years.

$29 \%(15 / 52)(95 \% \mathrm{CI}, 17-41)$ of attendings reported being injured within last 5 years compared to $40 \%$ of residents and $50 \%$ of fellows. Analyzing relationship between CPI within last 5 years and attending anesthesiologist's years of practice revealed an incidence of $57 \%$ for less than 5 years of practice, $31 \%$ for $5-10$ years of practice, $37.5 \%$ for $10-15$ years of practice, $20 \%$ for 15 20 years of practice, and 14\% for more than 20 years of practice (Table 2). 75\% (48/64) (95\% CI, 64-86) reported the incident at the time of injury (85\% of residents, $100 \%$ of fellows, $67.5 \%$ of attendings).

$59 \%(45 / 76)(95 \%$ CI, 48-70) of percutaneous injuries were due to hollow-bore objects and $41 \%$ were due to sharp objects (suture needle, scalpel, neuromonitoring needle) (Table 3). 84\% (38/45) of hollow bore injuries or 50\% (38/76) of all CPI were high risk (blood contaminated hollow-bore needle and lumen filled with undiluted blood). 
medRxiv preprint doi: https://doi.org/10.1101/2021.01.21.21249920; this version posted February 28, 2021. The copyright holder for this preprint (which was not certified by peer review) is the author/funder, who has granted medRxiv a license to display the preprint in perpetuity. All rights reserved. No reuse allowed without permission.

At the time of CPI, $16 \%(10 / 61)$ knew that the source had a history of blood-borne infection (1 HBV, $4 \mathrm{HCV}, 4 \mathrm{HIV}, 1 \mathrm{HIV}+\mathrm{HCV})$. When asked about postexposure prophylactic treatment, $26.6 \%(17 / 64)$ reported receiving it. $70.5 \%$ (12/17) of those who received HIV postexposure prophylactic treatment did not know, at the time of injury, that the source had an HIV infection. None $(0 / 64)$ of those who sustained percutaneous injury seroconverted. 


\section{Discussion}

This study revealed how incidence of CPI changes with years of practice, demonstrated how reporting of injuries has improved, described the specific nature of injuries in anesthesia practitioners, and assessed the need for postexposure prophylactic treatment after CPI. Results revised previously published data about incidence, reporting, characteristics, and outcome of percutaneous injuries in anesthesia residents, fellows, and attendings.

\section{Rate of injury}

Only few reports in the medical literature specifically address anesthesiologists' risk of occupational exposure and infection after CPI [2-7]. These reports, dating back to the 90s, have estimated an overall percutaneous exposure incidence of 1.35 CPIs per 1000 anesthetics, 0.42 CPIs per year per full time equivalent, 0.54 CPIs per 1000 hours of anesthesia, and 0.27 CPIs per year per person [2-4,7,11]. However, these estimates did not consider the effect of anesthesiologists' years of practice and experience on incidence of CPI. This study highlighted that most anesthesiologists will sustain a percutaneous injury during their careers, and that the incidence of CPI decreases with each 5 years of practice. (Table 2). Anesthesiologists with less than 15 years of practice had more than twice the incidence of CPI in the last 5 years compared to anesthesiologists with more than 15 years of practice $(39 \%(11 / 28)$ versus $17 \%(4 / 24))$. Other studies, not specific to anesthesiologists, also found that incidence of injuries gradually decreased with experience $[12,13]$. These findings underscore the importance of education and experience in the early years of anesthesia practice in preventing the occurrence of CPI thereafter. 
Several studies have documented CPI in various hospital departments, but none have been specific to anesthesia residents or fellows [14-19]. Our data showed that almost half of anesthesia residents and fellows sustain a CPI. Similarly, a survey targeting residents in the operative setting revealed that $34 \%(11 / 32)$ of anesthesia residents had a CPI compared to $99 \%$ of general surgery residents by the end of training $[14,15]$.

We did not inquire about incidence of CPI per postgraduate year of training or the circumstances of CPI in residents and fellows. However, surveys conducted in surgical residents showed that the mean number of needle stick injuries increases with every postgraduate year of training $[15,16]$. Lapses in concentration, fatigue, inexperience, feeling rushed, long work hours, and sleep deprivation have been attributed to CPIs [14,15,17-19]. Fatigue was reported as a contributing factor in 2 out of 3 of anesthesia residents compared to only 1 out of 5 surgical residents [14]. More research into causes of CPI in anesthesia residents and fellows is needed.

\section{Reporting}

Timely reporting of occupational exposures to an employee health service is necessary to ensure appropriate counseling, facilitate prophylaxis or early treatment, and establish legal prerequisites for workers' compensation [7, 14, 20]. Reporting can reduce rates of injury by identifying risk-prone behaviors and practices, and guide improvements in prevention [4]. Historically, reporting of needle sticks and sharp injuries to the workplace monitoring system by health care workers was $30 \%$ in the early 90 s and averaged $50 \%$ in the late 90 s and early 2000 [7, 15, 21-24]. In our survey, reporting of CPI by anesthesia attendings, residents, and fellows has tripled when compared to $19-29 \%$ historic numbers available in the anesthesia literature [7]. This denotes a significant improvement in reporting, although less than perfect. It seems that the same conditions that marred reporting of CPI still exist (perception of low risk, paperwork, time 
consuming, lack of knowledge about cost coverage) [14,15]. More education about the risks of disease transmission and emphasis on benefits of reporting injuries is needed to drive rates higher, particularly in anesthesia attendings [14,20].

\section{Type of injury}

Anesthesiologists are unique compared to other nonanesthesia operating room personnel in that they are more likely to sustain percutaneous injuries from hollow-bore needles than from sharp objects $[6,15,16,25]$. Blood-contaminated hollow-bore injuries carry a higher risk of pathogen transmission than injuries from sharp solid objects $[6,15,16]$. In the 90 s, Greene reported that $74 \%$ of CPI in anesthesiologists were associated with hollow-bore needles, and $30 \%$ of all CPI were high risk [7]. These trends continued in our survey with some decrease in percentage of hollow-bore needle injuries and increase in percentage of high-risk injuries. This may be explained by increased compliance with work practice modifications (avoidance of hollow-bore needle recapping) and prevalence of engineering solutions (shielding of hollow-bore needle tips after use).

\section{Outcome}

The risk of occupational infection with a blood-borne pathogen is proportional to the prevalence of patients carrying the pathogen, the risk of infection transmission, and the number of exposures to blood or body fluids $[4,6,26]$. In the hospital surgical setting, prevalence of $\mathrm{HIV}, \mathrm{HBV}$, and $\mathrm{HCV}$ is higher than that in the community [27]. Reports showed that $68.4 \%$ of seropositive cases for $\mathrm{HBV}, \mathrm{HCV}$, and $\mathrm{HIV}$ detected by preoperative screening tests were previously undiagnosed $[15,23]$. Similarly, $70 \%$ of those who received HIV prophylaxis in our survey did not know that the source had HIV infection at the time of injury. This confirms that 
there is a much higher risk of exposure to blood-borne pathogens than can be evaluated based on medical history alone perioperatively [14].

Published data estimates the risk of infection transmission after accidental percutaneous exposure to contaminated blood of $0.3 \%$ for $\mathrm{HIV}, 2 \%$ for $\mathrm{HCV}$, and up to $30 \%$ for $\mathrm{HBV}$ susceptible practitioners without post exposure prophylaxis or sufficient hepatitis B vaccination $[13,28-30]$. However, two recent studies in which $21 \%$ of health care workers received postexposure HIV prophylaxis reported $0 \%(0 / 266)$ HIV and $0.1 \%$ (2/1361) HCV seroconversions after percutaneous and mucocutaneous exposures to infected blood and body fluids [31, 32]. Results of our survey were similar and emphasized the frequent need for postexposure prophylaxis $(26 \%(17 / 64)$ after CPI and the very low seroconversion rates $(0 / 64)$.

Since the number of exposures to blood or body fluids could be altered, it is essential that anesthesiologists know and practice strategies that minimize percutaneous injuries. To this end, anesthesiologists must receive adequate training and supervision, avoid recapping by the twohanded technique, appropriately use needle and syringe disposal containers, dress all abrasions and cuts, eliminate unnecessary sharp devices, use needleless or protected needle devices, and wear protective barriers (personal protective clothing, gloves, masks, face shields) [4,7,28,33,34]. In addition, anesthesiologists should be informed about the importance of reporting injuries and following up with testing and/or prophylactic treatment [29].

\section{Limitations}

The results obtained are comparable to published literature and we have no reason to believe that its findings are not representative of the wider problem. However, some limitations should be considered. First, the survey is retrospective with likelihood of recall bias and overestimating or underestimating exposure incidents. Second, the response rate was $51 \%$ 
although the survey was short, anonymous, and a reminder to participate was sent. Such response rate underscores the possibility of non-response bias that could have selected those with strong attitudes towards the subject [35]. Non-response could also be due to nondelivered email, unfamiliarity with topic, and lack of motivation to participate. Nevertheless, some reports have called into question the possible association of nonresponse rate and response bias [36,37]. Third, the study is relatively small with possible concomitant attenuation of statistical power and precision [37]. In that regards, the maximum half width $95 \%$ CI for those who reported a percutaneous injury was $9 \%$. A future direction is a larger study to produce more data and allow for a more detailed subgroup analysis.

In conclusion, most anesthesiologists will sustain a contaminated percutaneous injury during their careers. Incidence of these injuries decreases with years of practice. Occurrence of these injuries is high among anesthesia residents, with the majority reporting their injuries. Most CPI in anesthesia personnel are due to hollow-bore needles with half of CPI being high risk and one-fourth receiving postexposure HIV prophylaxis. These findings underscore the need for more education and interventions to reduce occupational blood exposures and improve reporting. 


\section{References}

1. Kuhar DT, Henderson DK, Struble KA, et al; US Public Health Service Working Group. Updated US Public Health Service guidelines for the management of occupational exposures to human immunodeficiency virus and recommendations for postexposure prophylaxis. Infect Control Hosp Epidemiol. 2013;34(9):875-892.

2. Maz S, Lyons G. Needlestick injuries in anaesthetists. Anaesthesia 1990 Aug;45(8):677-8.

3. Harrison CA, Rogers DW, Rosen M: Blood contamination of anaesthetic and related staff. Anaesthesia. 1990;45:831-833.

4. Berry AJ, Greene ES. The risk of needlestick injuries and needlestick-transmitted diseases in the practice of anesthesiology. Anesthesiology. 1992;77:1007-21.

5. Tait AR, Tuttle DB. Prevention of occupational transmission of human immunodeficiency virus and hepatitis B virus among anesthesiologists: a survey of anesthesiology practice. Anesth Analg. 1994;79(4):623-8.

6. Greene ES, Berry AJ, Arnold WP 3rd, Jagger J. Percutaneous injuries in anesthesia personnel. Anesth Analg. 1996;83(2):273-8.

7. Greene ES, Berry AJ, Jagger J, Hanley E, Arnold WP, Bailey MK, Brown M, Gramling-Babb P, Passannante AN, Seltzer JL, Southorn P, Van Clief MA, Venezia. Multicenter study of contaminated percutaneous injuries in anesthesia personnel. Anesthesiol. 1998;89(6):1362-72. 
8. Jones D, Story D, Clavisi O, Jones R, Peyton P. An introductory guide to survey research in anaesthesia. Anaesth Intensive Care. 2006;34(2):245-53.

9. Agresti A, Caffo B. Simple and effective confidence intervals for proportions and differences of proportions result from adding two successes and two failures. Am Stat. 2000;54:280-288.

10. Sample size calculators. Confidence interval for a proportion. https://samplesize.net/confidence-interval-proportion/. Accessed 8 December 2020.

11. Popejoy SL, Fry DE. Blood contact and exposure in the operating room. Surg Gynecol Obstet. $1991 ; 172(6): 480-3$.

12. Abu-Gad H., Al-Turki KA. Some epidemiological aspects of needle stick injuries among the hospital health care workers: Eastern Province, Saudi Arabia. Eur J Epidemiol. 2001;17:401407.

13. Martins A, Coelho AC, Vieira M, Matos M, Pinto ML. Age and years in practice as factors associated with needlestick and sharps injuries among health care workers in a Portuguese hospital. Accid Anal Prev. 2012;47:11-5.

14. Sethi N, Evans D, Murray A. Needlestick Occurrences and Reporting Among Residents in the Operative Setting. J Surg Educ. 2020 Nov-Dec;77(6):1542-1551.

15. Makary M, Al-Attar A, Holzmueller CG, Sexton JB, Syin D., Gilson MM, Sulkowski MS, Pronovost PJ. Needlestick injuries among surgeons in training. NEJM. 2007;356: 2693-99.

16. Marnejon T, Gemmel D, Mulhern K. Patterns of needlestick and sharps injuries among training residents. JAMA Intern Med. 2016;176:251-2

17. Yang AD, Quinn CM, Hewitt DB, et al. National evaluation of needlestick events and reporting among surgical residents. J Am Coll Surg. 2019;229: 609-620. 
18. Ayas NT, Barger LK, Cade BE, Hashimoto DM, Rosner B, Cronin JW, Speizer FE, Czeisler CA. Extended work duration and the risk of self-reported percutaneous injuries in interns. JAMA. 2006;296(9):1055-62.

19. Fisman DN, Harris AD, Rubin M, Sorock GS, Mittleman MA. Fatigue increases the risk of injury from sharp devices in medical trainees: results from a case-crossover study. Infect Control Hosp Epidemiol. 2007;28(1):10-7.

20. Cicek-Senturk G, Tekin A, Gurbuz Y, et al. Retrospective investigation of 9 years of data on needlestick and sharps injuries: Effect of a hospital infection control committee. Am J Infect Control. 2019;47:186-190.

21. Kennedy R, Kelly S, Gonsalves S, Mc Cann PA. Barriers to the reporting and management of needlestick injuries among surgeons. Ir J Med Sci. 2009 Sep;178(3):297-9.

22. Quinn, M.M., Markkanen, P.K., Galligan, C.J., Kriebel, D., Chalupka, S.M., Kim, H., Gore,R.J., Sama, S.R., Laramie, A.K., Davis, L. Sharps injuries and other blood and body fluid exposures among home health care nurses and aides. Am. J. Public Health. 2009;99:S710-S717.

23. Alvarado-Ramy F, Beltrami EM, Short LJ, Srivastava PU, Henry K, Mendelson M, Gerberding JL, Delclos GL, Campbell S, Solomon R, Fahrner R, Culver DH, Bell D, Cardo DM, Chamberland ME. A comprehensive approach to percutaneous injury prevention during phlebotomy: results of a multicenter study, 1993-1995. Infect Control Hosp Epidemiol. 2003 Feb;24(2):97-104.

24. Lee JM, Boteman MF, Zanthakos N, Nicklasson L. Needlestick injuries in the United States: epidemiologic, economic and quality of life issues. AAOHN J. 2005;53:117-34. 
25. Bakaeen F, Awad S, Albo D, Bellows CF, Huh J, Kistner C, Izard D, Triebel J, Khan M, Berger DH. Epidemiology of exposure to blood borne pathogens on a surgical service. Am J Surg. 2006 Nov;192(5):e18-21.

26. Buergler JM, Kim R, Thisted RA, Cohn SJ, Lichtor JL, Roizen MF. Risk of human immunodeficiency virus in surgeons, anesthesiologists, and medical students. Anesth Analg. 1992;75(1):118-24.

27. Weiss ES, Makary MA, Wang T, et al. Prevalence of blood-borne pathogens in an urban, university-based general surgical practice. Ann Surg. 2005;241:803-9.

28. Beltrami EM, Williams IT, Shapiro CN, Chamberland ME. Risk and management of bloodborne infections in health care workers. Clin Microbiol Rev. 2000;13(3):385-407.

29. Centers for Disease Control and Prevention. Updated U.S. Public Health Service Guidelines for the Management of Occupational Exposures to HBV, HCV, and HIV and Recommendations for Postexposure Prophylaxis. MMWR 2001;50(No. RR-11):1-67.

30. Wicker S, Cinatl J, Berger A, Doerr HW, Gottschalk R, Rabenau HF. Determination of risk of infection with blood-borne pathogens following a needlestick injury in hospital workers. Ann Occup Hyg. 2008 Oct;52(7):615-22.

31. Nwaiwu CA, Egro FM, Smith S, Harper JD, Spiess AM. Seroconversion rate among health care workers exposed to HIV-contaminated body fluids: The University of Pittsburgh 13-year experience. Am J Infect Control. 2017 Aug 1;45(8):896-900.

32. Egro FM, Nwaiwu CA, Smith S, Harper JD, Spiess AM. Seroconversion rates among health care workers exposed to hepatitis $\mathrm{C}$ virus-contaminated body fluids: The University of Pittsburgh 13-year experience. Am J Infect Control. 2017 Sep 1;45(9):1001-1005. 
medRxiv preprint doi: https://doi.org/10.1101/2021.01.21.21249920; this version posted February 28, 2021. The copyright holder for this preprint (which was not certified by peer review) is the author/funder, who has granted medRxiv a license to display the preprint in perpetuity. All rights reserved. No reuse allowed without permission.

33. Bajwa SJ, Kaur J. Risk and safety concerns in anesthesiology practice: The present perspective. Anesth Essays Res. 2012 Jan-Jun;6(1):14-20.

34. Broussard IM, Kahwaji CI. Universal Precautions. 2020 Jul 26. In: StatPearls [Internet]. Treasure Island (FL): StatPearls Publishing; 2020 Jan.

35. Souki FG, Rodriguez-Blanco YF, Polu SR, Eber S, Candiotti KA. Survey of anesthesiologists' practices related to steep Trendelenburg positioning in the USA. BMC Anesthesiol. 2018 Aug 21;18(1):117.

36. Choung RS, Locke GR, Schleck CD, Ziegenfuss JY, Beebe TJ, Zinsmeister AR, Talley NJ. A low response rate does not necessarily indicate non-response bias in gastroenterology survey research: a population-based study. J Public Health. 2013;21:87-95.

37. Groves RM, Peytcheva E. The impact of nonresponse rates on nonresponse bias a metaanalysis. Public opinion quarterly. 2008 Jun 20;72(2):167-89. 


\section{Table 1. Survey data}

\begin{tabular}{|l|l|l|l|l|}
\hline & ALL & Residents & Fellows & Attendings \\
\hline Surveys sent & 217 & & & \\
\hline Surveys returned & $110 / 217$ & $50 / 85$ & $8 / 17$ & $52 / 115$ \\
& $51 \%$ & $59 \%$ & $47 \%$ & $45 \%$ \\
\hline Anesthesiologists with CPI & $65 / 110$ & $21 / 50$ & $4 / 8$ & $40 / 52$ \\
& $59 \%$ & $42 \%$ & $50 \%$ & $77 \%$ \\
\hline Anesthesiologist with 1 CPI & 35 & $14 / 21$ & $2 / 4$ & $19 / 40$ \\
\hline Anesthesiologist with 2 CPI & $54 \%$ & $67 \%$ & $50 \%$ & $47.5 \%$ \\
\hline Anesthesiologist with $\geq 3$ CPI & 22 & $6 / 21$ & $2 / 4$ & $14 / 40$ \\
& $34 \%$ & $28 \%$ & $50 \%$ & $35 \%$ \\
\hline Number of CPI per anesthesiologists who & $113 / 110$ & $29 / 50$ & $6 / 8$ & $78 / 52$ \\
answered survey & 1.03 & 0.58 & 0.75 & 1.5 \\
\hline Anesthesiologists with CPI last 5 years & $39 / 110$ & $20 / 50$ & $4 / 8$ & $15 / 52$ \\
& $35 \%$ & $40 \%$ & $50 \%$ & $29 \%$ \\
\hline
\end{tabular}


medRxiv preprint doi: https://doi.org/10.1101/2021.01.21.21249920; this version posted February 28, 2021. The copyright holder for this preprint (which was not certified by peer review) is the author/funder, who has granted medRxiv a license to display the preprint in perpetuity.

All rights reserved. No reuse allowed without permission.

\begin{tabular}{|l|l|l|l|l|}
\hline Anesthesiologists reported CPI at time of injury & $48 / 64$ & $17 / 20$ & $4 / 4$ & $27 / 40$ \\
& $75 \%$ & $85 \%$ & $100 \%$ & $67.5 \%$ \\
\hline $\begin{array}{l}\text { Anesthesiologists received postexposure } \\
\text { prophylaxis }\end{array}$ & $17 / 64$ & $6 / 20$ & $3 / 4$ & $8 / 40$ \\
\hline
\end{tabular}

Table 2. Percutaneous injuries reported by attending anesthesiologists compared to years of practice (Total).

\begin{tabular}{|l|l|l|l|l|l|}
\hline Years of practice & $<5$ & $5-10$ & $10-15$ & $15-20$ & $>20$ \\
\hline Attendings responded (52) & 7 & 13 & 8 & 10 & 14 \\
\hline Anesthesiologists reported CPI (40) & $13.5 \%$ & $25 \%$ & $15.5 \%$ & $19 \%$ & $27 \%$ \\
\hline Number of CPI per anesthesiologists who & $10 / 7$ & $13 / 13$ & $10 / 8$ & $20 / 10$ & $25 / 14$ \\
\hline answered survey (78) & $100 \%$ & $69 \%$ & $62.5 \%$ & $80 \%$ & $78.5 \%$ \\
\hline Reported having CPI in last 5 years (15) & $4 / 7$ & $4 / 13$ & $3 / 8$ & $2 / 10$ & $2 / 14$ \\
\hline
\end{tabular}


Table 3. Devices causing contaminated percutaneous injuries (CPI).

\begin{tabular}{|l|l|l|}
\hline \multirow{3}{*}{$41 \%$} & Type of Device & CPI (n) \\
\hline \multirow{5}{*}{ Solid } & Suture needle & 21 \\
\cline { 2 - 3 } & Scalpel & 6 \\
\cline { 2 - 3 } & Other (J tube wire, head frame pins) & 2 \\
\cline { 2 - 3 } & Neuromonitoring needle & 2 \\
\hline \multirow{3}{*}{$59 \%$} & Spinal or Epidural needle & 4 \\
\cline { 2 - 3 } & Nerve block needle & 38 \\
\cline { 2 - 3 } & Hollow-bore needle (venous, arterial, central) & 76 \\
\hline Total & & 38 \\
\hline
\end{tabular}




\section{Appendix}

\section{Survey Questions}

1. What is your Age?
A. $\quad 25-34$
B. $35-44$
C. $\quad 45-54$
D. $55-64$
E. $>65$

2. What is your gender?
A. Female
B. Male

3. Which of the following best describes your current job level?
A. Resident
B. Fellow
C. Attending

4. About how many years have you been practicing anesthesia?
A. Less than 5 years
B. At least 5 years but less than 10 years
C. At least 10 years but less than 15 years
D. At least 15 years but less than 20 years
E. 20 years or more

5. In your years of anesthesia practice, how many times have you been injured by a CONTAMINATED sharp object/needle?
A. 0
B. 1 

C. 2
D. 3
E. 4
F. 5
G. More than 5

6. Have you had any accidental injury by a CONTAMINATED sharp object/needle in the past 5 years?
A. Yes
B. No

7. Which of the following contaminated devices caused the injury? (Choose all that apply)
A. Suture needle
B. Regional anesthesia needle
C. Spinal or epidural needle
D. Hollow-bore needle ( venous, arterial, central)
E. Sharp object (scalpel)
F. Other (please specify)

8. What was the viral status of the patient at the time of injury? (Choose all that apply)
A. HIV positive
B. HBV positive
C. HCV positive
D. Unknown
E. Other (please specify)

9. Did you report your injury to your supervisor or medical health services when it occurred?
A. Yes
B. No

10. Did you receive post exposure prophylactic treatment?
A. Yes
B. No

11. Did you seroconvert (i.e. acquire infection)?

A. Yes 
medRxiv preprint doi: https://doi.org/10.1101/2021.01.21.21249920; this version posted February 28, 2021. The copyright holder for this preprint (which was not certified by peer review) is the author/funder, who has granted medRxiv a license to display the preprint in perpetuity.

All rights reserved. No reuse allowed without permission.

B. $\mathrm{No}$ 